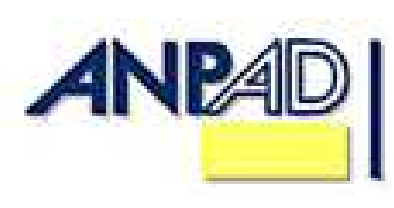

Available online at http://www.anpad.org.br/bar

BAR, Rio de Janeiro, v. 9, n. 3, art. 6, pp. 351-373, July/Sept. 2012

\title{
Credit Card Risk Behavior on College Campuses: Evidence from Brazil
}

\author{
Wesley Mendes-Da-Silva * \\ E-mail address: mr.mendesdasilva@gmail.com \\ Fundação Getulio Vargas - EAESP/FGV \\ São Paulo, SP, Brazil. \\ Wilson Toshiro Nakamura \\ E-mail address: wtnakamura@uol.com.br \\ Universidade Presbiteriana Mackenzie \\ São Paulo, SP, Brazil. \\ Daniel Carrasqueira de Moraes \\ E-mail address: daniel@lavill.com.br \\ Universidade Presbiteriana Mackenzie \\ São Paulo, SP, Brazil.
}

Copyright (C) 2012 Brazilian Administration Review. All rights reserved, including rights for translation. Parts of this work may be quoted without prior knowledge on the condition that the source is identified. 


\begin{abstract}
College students frequently show they have little skill when it comes to using a credit card in a responsible manner. This article deals with this issue in an emerging market and in a pioneering manner. University students $(n=769)$ in São Paulo, Brazil's main financial center, replied to a questionnaire about their credit card use habits. Using Logit models, associations were discovered between personal characteristics and credit card use habits that involve financially risky behavior. The main results were: (a) a larger number of credit cards increases the probability of risky behavior; (b) students who alleged they knew what interest rates the card administrators were charging were less inclined to engage in risky behavior. The results are of interest to the financial industry, to university managers and to policy makers. This article points to the advisability, indeed necessity, of providing students with information about the use of financial products (notably credit cards) bearing in mind the high interest rates which their users are charged. The findings regarding student behavior in the use of credit cards in emerging economies are both significant and relevant. Furthermore, financial literature, while recognizing the importance of the topic, has not significantly examined the phenomenon in emerging economies.
\end{abstract}

Key words: credit cards; young adults; consumers; emerging market; personal finance. 


\section{Introduction}

University students frequently find themselves at a time in their lives when they have growing responsibilities and are obliged to make decisions that will define their financial independence and have consequences for their future well-being and security. Decision-making methods and the financial habits of citizens, especially university students, have received considerable attention from both governments and the financial industry. However, with the exception of the United States, what is seen is that this issue is being studied in less depth in the academic environment than in the finance community, especially when considering emerging markets like Brazil.

The main role of financial innovation is to promote the well-being of society through a reduction in the cost of capital, promoting greater efficiency and facilitating the control of consumption and investment decisions, with considerable benefits for borrowers and investors alike; i.e. families, corporations and governments (Sánchez, 2010, p. 27). Therefore, it becomes imperative to carry out studies that seek to throw light on this topic, bearing in mind just how relevant a better understanding of the credit-related behavior of young adults is. The main objectives of this study are to: (a) identify and characterize those students who were most at risk for mismanaging and misusing credit cards; (b) identify some of the hidden consequences of financial mismanagement for students; and (c) provide some insight into educational resources and services that could be developed to help students better manage their credit card debt and other finances. For the development of this research, in 2011 we collected 769 valid questionnaires from university students in Sao Paulo, Brazil's main financial center. In this context, the relevance of the university's role is clear to see. This is an environment that is, of necessity, well-placed for educating students because of the influence it exercises over their behavior.

In terms of individuals' access to credit there is little doubt that currently this has a strong influence on the lifestyle of people, providing them with convenience, social status and purchasing power. However, the indiscriminate use of credit cards can have a considerably harmful effect on well-being (Bernthal, Crockett, \& Rose, 2005). The negative reflections of the inconsequential financial behavior of young adults may constitute a great difficulty in their academic performance, in addition to compromising their physical and mental health (Lyons, 2004, 2007).

According to research in economic psychology, high levels of financial stress are often associated with increased levels of psychological and physical stress (Lyons \& Yilmazer, 2005; MacFadyen, MacFadyen, \& Prince, 1996). Along this same line of thinking, studies have documented the high levels of indebtedness of students, who sometimes seek to finance their studies, whether by paying college fees or even buying college material, with funds coming from their credit card (Nellie Mae, 2005). In 2010, the amount owed on American college student loans overtook credit card debt, and the current amassed student loan debt is approaching one trillion dollars, as reported by print media in the USA (Cauchon, 2011). Concerns are emerging about the consequences of this debt. For example, recent work in Canada reported that those workers with more student loans were less likely to own their own homes or to have savings or investments (Luong, 2010). The net result of this is a panorama of high indebtedness, which in some cases even leads students to committing suicide. In the United States government and school managers have introduced restrictions on requests for credit cards on college campuses (Norvilitis \& Santa Maria, 2002). A significant portion of the Brazilian higher education system consists of public (federal and state) universities, which are tuition free. This results in types of school-related expenditures that are quite different (college material for example) from those in the USA; and the credit card industry and credit reporting system are also highly disparate. We realize that most of the relevant literature on this topic comes from beyond Brazil, and even though this article mostly considers students in private universities, it is intended to fill this gap.

The main contribution of this study to the finance field is to offer, in a pioneering way, empirical evidence of associations between the profile of university students and the occurrence of risk 
behavior in the use of credit cards in an emerging market. From the 769 valid responses collected in São Paulo/Brazil, using Logit models, the main results suggests that financial education may contribute to positive behavior when using a credit card. These findings are essentially of interest to public policy makers (Mansfield \& Pinto, 2007), the financial industry (Fogel \& Schneider, 2011), and school managers (Lyons, 2007).

This paper is organized into five sections, including this introduction. The second section presents the theoretical and empirical bases that support this research. The third section details the methodological procedures. The fourth section discusses the empirical results. The paper concludes with final considerations.

\section{Background}

Over the last two decades there has been an increase in the use of credit cards by university students (Manning, 2000; Nellie Mae, 2005; U.S. General Accounting Office, 2001), making it necessary to better understand the behavior of this particular public. Since the last decade the volume of credit in the Brazilian economy has grown strongly. According to studies by the financial industry of the Brazilian National Finance System, between January, 2004, and January, 2011, the bank lending/Gross Domestic Product ratio went from $24.3 \%$ to $46.5 \%$. At the same time, the volume of credit went from $\sim \mathrm{R} \$ 417.8$ billion to $\sim \mathrm{R} \$ 1.71$ trillion, essentially due to growth in personal credit, which represented $\sim 38 \%$ of all lending. At the end of this same period, it reached $\sim 46 \%$ of the credit stock, at $\sim \mathrm{R} \$ 787.1$ billion (Departamento de Pesquisas Econômicas do Bradesco [Depec], 2011). When this is associated with the growth in the credit card market (see Figure 1) it becomes possible to arrive at a reasonable estimate for the size of the card industry.

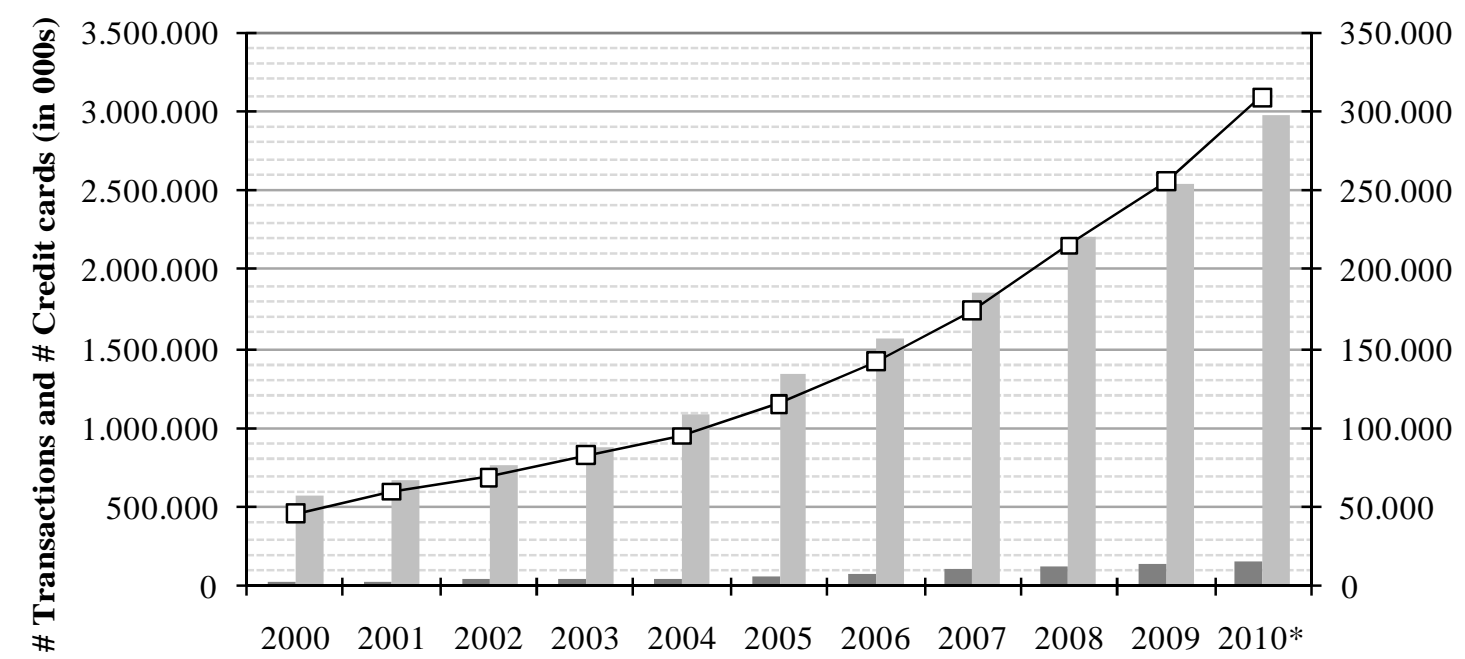

Cards (in 000s) $\quad$ Transactions (in 000s) $\quad-\square \quad$ Billings (R\$ million)

Figure 1. Evolution of Credit Card Use Statistics in Brazil.

This graph shows the evolution of three measures relating to credit card use in Brazil: \# Credit cards (in 000s); \# Transactions (in 000s); billings (in R \$ million). Between 2000 and 2009 (*the numbers for 2010, as at the latest version of this paper, were still estimates) there was strong growth in the credit card market in Brazil. Throughout this period, therefore, for the: \# Credit cards: $\Delta \%=379 \%$; \# Transactions: $\Delta \%=346 \%$; and billings: $\Delta \%=460 \%$.

Source: Based on data from the Brazilian Association of Credit Card and Service Companies. (2011). Indicadores de mercado. Retrieved from http://www.abecs.org.br/site2012/indicadores.asp

The line of work that is supported by the traditional Life Cycle Theory with budgetary restrictions, as proposed by Modigliani (1998),provides provocative insights into the financial 
decisions taken by individuals, including the inter-generational transfer of financial behavior; i.e. the reasons why students get into debt (Lyons, Scherpf, \& Neelakantan, 2007).The conceptual model of this research assumes that financial behavior has an impact on the well-being of individuals within the personal finance area and that this has repercussions on their mental and physical health, academic performance and satisfaction with life (Kahneman, Krueger, Schkade, Schwarz, \& Stone, 2006; Xiao, Noring, \& Anderson, 1995).

Studies relating to behavior with credit cards usually combine knowledge from different fields, e.g.: economics, sociology and psychology, following a connected domain approach, which is also sought in this study. Two approaches can be found in these works. One line focuses on social and economic psychology, which explores student attitudes, perceptions and behavior vis-a-vis credit cards and money in general (Danes \& Hira, 1987; Fan \& Xiao, 1998; Hayhoe, 2002; Kidwell \& Turrisi, 2000; Markovich \& Devaney, 1997; Masuo, Malroutu, Hanashiro, \& Kim, 2004; Rindfleisch, Burroughs, \& Denton, 1997; Roberts \& Jones, 2001).

The other line of work, which deals more specifically with student behavior with regard to credit cards, uses concepts of applied economics for documenting patterns of association between demographic aspects and habits in the use of credit cards (Allen \& Jover, 1997; Hayhoe, 2002; Joo, Grable, \& Bagwell, 2003; Lawrence, Cude, Lyons, Marks, \& Machtmes, 2006; Lyons, 2004, 2007; U.S. General Accounting Office, 2001; Xiao et al., 1995). This work follows the latter line of thinking.

In Brazilian literature no significant attention has yet been paid to the theme of consumer behavior relative to credit card services. As far as we know there is just one piece of research in this area, which was carried out by Veludo-de-Oliveira, Ikeda and Santos (2004), who concentrated on exploring personal characteristics. There are other studies that support a structured analysis of the formation of financial behavior and how this behavior extends to impact on the well-being of young adults, as presented in Table 1.

Table 1

Summary of the Main Empirical Works on the Credit Behavior of University Students

\begin{tabular}{|c|c|c|c|}
\hline Author & Objective & Method & Key Results \\
\hline $\begin{array}{l}\text { Fogel and } \\
\text { Schneider } \\
(2011)\end{array}$ & $\begin{array}{l}\text { To check associations between } \\
\text { the student's profile and risk } \\
\text { behavior with money. }\end{array}$ & $\begin{array}{l}\text { Application of ANOVA and } \\
\text { ANCOVA from a survey of } \\
301 \text { students in New York. }\end{array}$ & $\begin{array}{l}\text { The higher the income, the } \\
\text { greater the compulsive buying } \\
\text { and money problems. }\end{array}$ \\
\hline $\begin{array}{l}\text { Veludo-de- } \\
\text { Oliveira et al. } \\
\text { (2004) }\end{array}$ & $\begin{array}{l}\text { To investigate the influence of } \\
\text { credit cards on compulsive } \\
\text { buying behavior. }\end{array}$ & $\begin{array}{l}\text { Exploratory study (they used } \\
\text { the Likert scale) of } 188 \text { young } \\
\text { adults in São Paulo/Brazil. }\end{array}$ & $\begin{array}{l}\text { Young adults with a propensity } \\
\text { for compulsiveness use credit } \\
\text { cards more intensely. }\end{array}$ \\
\hline $\begin{array}{l}\text { Masuo et al. } \\
(2004)\end{array}$ & $\begin{array}{l}\text { To analyze the beliefs and } \\
\text { behavior of students with } \\
\text { regard to money. }\end{array}$ & $\begin{array}{l}\text { Factor analysis of } 290 \text { Asian } \\
\text { and North American university } \\
\text { students, exploring } \\
\text { intercultural constructs. }\end{array}$ & $\begin{array}{l}\text { They found three factors: } \\
\text { Power, security and finances. } \\
\text { Asians strongly believe that } \\
\text { money brings power and } \\
\text { security. }\end{array}$ \\
\hline $\begin{array}{l}\text { Pinto, Parente } \\
\text { and Palmer } \\
(2001)\end{array}$ & $\begin{array}{l}\text { To check if the academic } \\
\text { performance of students is in } \\
\text { any way associated with their } \\
\text { behavior when using credit } \\
\text { cards. }\end{array}$ & $\begin{array}{l}\text { Survey of } 260 \text { students } \\
\text { (classified into groups with } \\
\text { high and low academic } \\
\text { performance) from } 3 \\
\text { universities in the United } \\
\text { States. }\end{array}$ & $\begin{array}{l}\text { They found no association } \\
\text { between academic } \\
\text { performance and behavior in } \\
\text { the use of credit cards. }\end{array}$ \\
\hline
\end{tabular}


Table 1 (continued)

\begin{tabular}{|c|c|c|c|}
\hline Author & Objective & Method & Key Results \\
\hline $\begin{array}{l}\text { Hayhoe, } \\
\text { Leach, Turner, } \\
\text { Bruin and } \\
\text { Lawrence } \\
(2000)\end{array}$ & $\begin{array}{l}\text { To check feelings about the } \\
\text { credit cards that students use. }\end{array}$ & $\begin{array}{l}\text { OLS regression of students in } \\
\text { the United States }(N=480) \text {. }\end{array}$ & $\begin{array}{l}\text { Women tend to spend more on } \\
\text { clothes, while men buy more } \\
\text { electronic goods. The gender } \\
\text { variable has more influence on } \\
\text { the forecast of financial } \\
\text { management practices than on } \\
\text { the actual attitude to credit. }\end{array}$ \\
\hline $\begin{array}{l}\text { Hayhoe, } \\
\text { Leach and } \\
\text { Turner (1999) }\end{array}$ & $\begin{array}{l}\text { To check the reasons for using } \\
\text { credit cards. }\end{array}$ & $\begin{array}{l}\text { Logit regression and OLS, of } \\
480 \text { students in the United } \\
\text { States. }\end{array}$ & $\begin{array}{l}\text { The significant predictors } \\
\text { were: actual attitude to credit, } \\
\text { age, the cognitive attitude to } \\
\text { credit and gender. }\end{array}$ \\
\hline $\begin{array}{l}\text { Fan and Xiao } \\
\text { (1998) }\end{array}$ & $\begin{array}{l}\text { To study the profile of young } \\
\text { adult Chinese as to how they } \\
\text { make buying decisions. }\end{array}$ & $\begin{array}{l}\text { Comparative study using } \\
\text { Factor Analysis, taken from } \\
271 \text { questionnaires applied in } 5 \\
\text { Chinese universities. }\end{array}$ & $\begin{array}{l}\text { There was found to be a } \\
\text { similarity in dimension and } \\
\text { profile between the decision- } \\
\text { making process of Chinese } \\
\text { students and the results } \\
\text { obtained with students in the } \\
\text { United States and South } \\
\text { Korea. }\end{array}$ \\
\hline $\begin{array}{l}\text { Rindfleisch, } \\
\text { Burroughs and } \\
\text { Denton (1997) }\end{array}$ & $\begin{array}{l}\text { To analyze associations } \\
\text { between family structure and } \\
\text { attitude with regard to } \\
\text { consumption. }\end{array}$ & $\begin{array}{l}\text { Analysis by MANOVA, with } \\
138 \text { questionnaires. }\end{array}$ & $\begin{array}{l}\text { Family structure is related both } \\
\text { to materialism and compulsive } \\
\text { consumption. }\end{array}$ \\
\hline $\begin{array}{l}\text { Danes and } \\
\text { Hira (1987) }\end{array}$ & $\begin{array}{l}\text { To describe student knowledge } \\
\text { of financial administration, } \\
\text { explaining their skill } \\
\text { differences as a function of } \\
\text { this knowledge. }\end{array}$ & $\begin{array}{l}\text { Pearson correlation and least } \\
\text { squares correlation, from data } \\
\text { collected from } 323 \\
\text { respondents. }\end{array}$ & $\begin{array}{l}\text { On average, students need } \\
\text { greater financial knowledge. } \\
\text { Their knowledge about } \\
\text { insurance, credit and other } \\
\text { areas of finance was } \\
\text { superficial. }\end{array}$ \\
\hline
\end{tabular}

\section{Method}

\section{Data collection and variables}

The questionnaire used to collect data about variables of interest was translated to Portuguese and adapted from Lyons $(2004,2007)$. It is divided into three parts, as can be seen in Appendix: (a) Use and knowledge of aspects relating to credit; (b) Financial education; and (c) Social profile. Before being applied to respondents, the questionnaire was submitted to ten experienced professionals from the credit card industry, working in eight different firms that use credit risk analysis, in order to identify necessary adjustments to the Brazilian reality.

After fifteen days of analysis, these senior analysts suggested adapting two variables concerning risk behavior: (a) existing debt on a credit card equal to or higher than $\mathrm{R} \$ 1,000.00$; and (b) an individual having three or more credit cards. Data were collected in February and March 2011 from university students from different higher education institutions in São Paulo. The students were randomly approached on the following university campuses, with corresponding percentages of the sample: Presbyterian University Mackenzie (35.6\%), Fundação Armando Álvares Penteado (FAAP) [15\%], Fundação Escola de Comércio Álvares Penteado (Fecap) [13\%], Fundação Getulio Vargas 
(FGV-EAESP) [10\%], Faculdade de Economia, Administração e Contabilidade da Universidade de São Paulo (FEA/USP) [15.8\%], Universidade Bandeirantes [10.6\%].

As assumed by Lyons (2004), students who took place in the survey were classified as being financially risky when at least one of the following four characteristics was found, which constituted the dependent variables (dummy, with a value $=1$ when risk behavior was found, and zero if not): (a) the existing balance on the credit card is currently equal to or more than $\mathrm{R} \$ 1,000.00$ (see $\mathrm{Q} 4$ ). Perhaps this variable should be used as a percentage of household income (or individual), but due to the unwillingness of students to inform their family income, we used the value of $\$ 1,000$, as suggested by area experts. In view of homogeneity of the demographic group of participants, the primary problems were: (b) delay in paying a bill by 60 days or more within the last two years (see Q5); (c) used the full limit of the credit card within the last two years (see Q7); (d) paid off the full amount of the statement sporadically, or never, within the last two years (Q6). Based on these four variables, a fifth dependent variable was obtained: (e) displays at least one of these four behaviors.

As independent variables (dummy) 22 factors are used (listed in Table 2), organized into three groups, namely: (a) Demographic aspects; (b) Financial behavior; (c) Types of credit card use. It is worth pointing out that some factors may be endogenous. However, due to limitations in the data it was not possible to obtain instruments for controlling for the possibility of endogeneity. So, it is assumed that these values can be exogenously determined. The error term, $u_{i}$, is assumed as being normally distributed, with a mean of zero and a variance equal to 1 . 
Table 2

\section{Frequency (in \%) of the Profile Variables of the Respondents (in Accordance with the Risk Extracts of the Individuals)}

\begin{tabular}{|c|c|c|c|c|c|c|c|c|}
\hline \multirow[b]{2}{*}{$\begin{array}{l}\text { Independent variables of the regressions } \\
\text { (all dummies with the value }=1 \text { if the } \\
\text { affirmation was seen) }\end{array}$} & \multirow[b]{2}{*}{$\begin{array}{c}\text { All students } \\
(\mathrm{N}=769)\end{array}$} & \multirow[b]{2}{*}{$\begin{array}{l}\text { Students } \\
\text { with cc } \\
(\mathrm{N}=552)\end{array}$} & \multirow[b]{2}{*}{$\begin{array}{l}\text { No risk with } \\
\text { cc } \\
(\mathrm{N}=358)\end{array}$} & \multirow[b]{2}{*}{$\begin{array}{l}\text { At risk with } \\
\text { cc } \\
(\mathrm{N}=195)\end{array}$} & \multicolumn{4}{|c|}{ Groups of students at risk $(\mathrm{N}=195)$} \\
\hline & & & & & $\begin{array}{l}\text { Debts on credit } \\
\text { card } \geq R \$ 1000 \\
\qquad(\mathrm{~N}=104)\end{array}$ & $\begin{array}{l}\text { Delay in } \\
\text { paying cc bills } \\
(\mathrm{N}=49)\end{array}$ & $\begin{array}{l}\text { Does not pay full } \\
\text { amount of card } \\
\text { bill } \\
(\mathrm{N}=76)\end{array}$ & $\begin{array}{l}\text { Uses full limit of } \\
\text { credit card } \\
(\mathrm{N}=51)\end{array}$ \\
\hline$\underline{\text { Demographics }}$ & - & - & - & - & - & - & - & - \\
\hline Male & 49.0 & 47.5 & 43.6 & 54.3 & 53.8 & 40.8 & 44.7 & 54.9 \\
\hline In relationship & 5.0 & 4.6 & 3.1 & 7.1 & 12.9 & 6.5 & 2.7 & 3.9 \\
\hline Family lives in own home & 90.7 & 91.0 & 92.7 & 87.5 & 90.3 & 81.6 & 84.0 & 88.0 \\
\hline 1st generation university student & 10.1 & 10.7 & 9.6 & 12.3 & 11.8 & 17.0 & 13.5 & 8.0 \\
\hline Lives in rented property/resid. hall & 17.0 & 16.8 & 16.0 & 18.1 & 16.0 & 19.6 & 17.3 & 18.0 \\
\hline Obtained cc the first year of college & 44.6 & 62.2 & 62.9 & 60.8 & 60.6 & 63.3 & 60.5 & 52.9 \\
\hline$\underline{\text { Financial behavior }}$ & - & - & - & - & - & - & - & - \\
\hline Financially independent of parents & 24.1 & 26.3 & 22.2 & 33.3 & 40.4 & 38.8 & 34.7 & 28.0 \\
\hline Has 3 or more cc & 12.2 & 17.0 & 12.0 & 26.1 & 34.6 & 28.6 & 23.7 & 25.5 \\
\hline Financial situation affects concentration & 16.8 & 17.0 & 13.1 & 24.0 & 26.2 & 25.5 & 31.1 & 26.0 \\
\hline Sleeping diff. because of finances in past & 21.1 & 21.1 & 16.3 & 29.2 & 35.6 & 31.2 & 37.3 & 26.0 \\
\hline Would do pers. finance course online & 70.5 & 70.5 & 69.5 & 72.0 & 76.0 & 80.4 & 76.3 & 76.5 \\
\hline Would do pers. finance course at univ. & 81.6 & 81.5 & 82.4 & 79.6 & 81.0 & 87.0 & 81.3 & 80.4 \\
\hline Knows cc interest rates & 30.9 & 43.3 & 49.9 & 31.0 & 26.2 & 27.1 & 24.0 & 28.6 \\
\hline Uses cc to pay expenses of: & - & - & - & - & - & - & - & - \\
\hline Education (e.g. books) & 17.0 & 23.7 & 24.6 & 22.0 & 31.7 & 16.3 & 21.1 & 19.6 \\
\hline
\end{tabular}

Continues 
Table 2 (continued)

\begin{tabular}{|c|c|c|c|c|c|c|c|c|}
\hline \multirow[b]{2}{*}{$\begin{array}{l}\text { Independent variables of the regressions } \\
\text { (all dummies with the value }=1 \text { if the } \\
\text { affirmation was seen) }\end{array}$} & \multirow[b]{2}{*}{$\begin{array}{c}\text { All students } \\
(\mathrm{N}=769)\end{array}$} & \multirow[b]{2}{*}{$\begin{array}{l}\text { Students } \\
\text { with cc } \\
(\mathrm{N}=552)\end{array}$} & \multirow[b]{2}{*}{$\begin{array}{l}\text { No risk with } \\
\text { cc } \\
(\mathrm{N}=358)\end{array}$} & \multirow[b]{2}{*}{$\begin{array}{l}\text { At risk with } \\
\qquad \mathrm{cc} \\
(\mathrm{N}=195)\end{array}$} & \multicolumn{4}{|c|}{ Groups of students at risk $(\mathrm{N}=195)$} \\
\hline & & & & & $\begin{array}{l}\text { Debts on credit } \\
\text { card } \geq \mathrm{R} \$ 1000 \\
\quad(\mathrm{~N}=104)\end{array}$ & $\begin{array}{l}\text { Delay in } \\
\text { paying cc bills } \\
(\mathrm{N}=49)\end{array}$ & $\begin{array}{l}\text { Does not pay full } \\
\text { amount of card } \\
\text { bill } \\
(\mathrm{N}=76)\end{array}$ & $\begin{array}{l}\text { Uses full limit of } \\
\text { credit card } \\
(\mathrm{N}=51)\end{array}$ \\
\hline Clothes and pers. items & 46.2 & 63.9 & 66.8 & 58.4 & 65.4 & 53.1 & 52.6 & 60.8 \\
\hline Meals & 28.3 & 39.5 & 41.6 & 35.3 & 40.4 & 26.5 & 31.6 & 29.4 \\
\hline Entertainment (e.g. cinema and theater) & 37.7 & 52.4 & 53.1 & 50.7 & 47.1 & 46.9 & 47.4 & 47.1 \\
\hline Automobiles (e.g. fuel and maintenance) & 20.2 & 27.9 & 25.1 & 32.8 & 44.2 & 20.4 & 22.4 & 27.5 \\
\hline Travel & 19.0 & 26.1 & 26.0 & 26.1 & 40.4 & 14.3 & 19.7 & 19.6 \\
\hline Rent & 1.6 & 2.2 & 2.0 & 2.5 & 3.8 & 6.1 & 2.6 & 2.0 \\
\hline Payment of general accounts & 4.9 & 6.9 & 6.1 & 8.2 & 9.6 & 14.3 & 10.5 & 5.9 \\
\hline Diverse expenses & 6.5 & 9.1 & 6.4 & 13.8 & 20.2 & 12.2 & 14.5 & 9.8 \\
\hline
\end{tabular}

Note. \% calculated based on valid frequencies (i.e. ignoring missing values). Students with cc represents students who have at least one credit card; No risk with cc identifies students who have a credit card but who have no risk behavior; At risk with ce identifies students who have a credit card and at least one risk behavior. The remaining columns classify students by risk behavior. 


\section{Tests and the empirical model}

We use two test procedures, in addition to descriptive statistics: (a) non-parametric tests of independence (which showed independence between family income and adoption of risky behaviors in the use of credit cards); (b) analysis of Logit models, intended to estimate the likelihood of risky behavior by the respondent profile. As mentioned, binary non-linear regression models are used in this research. The two most widely used approaches in financial literature for this purpose are the Logit and Probit models, with the first being widely used for convenience (mathematical), bearing in mind the practicality for interpreting the estimated parameters (Aldrich \& Nelson, 1984; Dietrich \& Sorensen, 1984).

The estimated parameters in the regressions may be assumed from the descriptive (to the extent that they try to describe the nature of associations between the mean response; i.e. the probability of a student having a high debit balance, for example, with the 22 regressor variables), and predictive (i.e.: to estimate if a student will assume risk behavior, given his/her demographic profile and his/her credit card use habits) points of view. The logistic function (for the case of a single predictor variable) is given by the expression (1), as follows:

$$
E\left(Y_{i} \mid X_{i}\right)=\pi_{i}=\frac{\exp \left(\beta_{0}+\beta_{1} X_{i}\right)}{1+\exp \left(\beta_{0}+\beta_{1} X_{i}\right)} \therefore \frac{1}{1+e^{-\left(\beta_{0}+\beta_{1} X_{i}\right)}}
$$

which is equivalent to (2):

$$
E\left(Y_{i} \mid X_{i}\right)=\pi_{i}=\left[1+\exp \left(-\beta_{0}-\beta_{1} X_{i}\right)\right]^{-1}
$$
have (3):

However, in the case of a binary response regression model, comprising k regressors, we

$$
E\left(Y_{i} \mid X_{i}\right)=\pi_{i}=\left[1+\exp \left(-\boldsymbol{\beta}^{\prime} \boldsymbol{X}\right)\right]^{-1}
$$

with:

$$
\boldsymbol{\beta}^{\prime} \boldsymbol{X}=\beta_{0}+\beta_{1} X_{1}+\beta_{2} X_{2}+\cdots+\beta_{k} X_{k}
$$

\section{Results}

\section{Exploratory analysis of the data}

Examining Figure 2, it can be seen that the whole group $(\mathrm{N}=769)$ of respondents (whether they have a credit card or not), both male and female, attributed great relevance to issues relating to: (a) investments, (b) credit cards, and (c) private pension schemes. In addition, there is a significant possibility for training individuals in the savings, investments and private pension areas, especially regarding responses from females.

Figure 2 shows the relevance and level of alleged knowledge of financial products on the part of the participating students for both male and female individuals. The Mann-Whitney U Test revealed an independence between gender and any relevance attributed by the respondents. In the case of financial product knowledge, independence was also observed between these variables, with the exception of Financing Vehicles and Savings and Investments ( $p<0.01 ; N=$ 769). The results suggest that male individuals, to a significant extent, tended to allege they had great knowledge of these two financial products.

Of the 552 students who had credit cards 195 , approximately $35.3 \%$, were classified as having at least one risk behavior. In this sense, $136(\sim 69.7 \%)$ of the 195 people identified as 'at 
risk' were classified into just one of the four possible behaviors, thirty-eight students were classified in two risk behaviors simultaneously, sixteen students had three behaviors, and only five of the 194 students alleged they had four risk behaviors.

Female respondents $(\mathrm{N}=392[51 \%])$

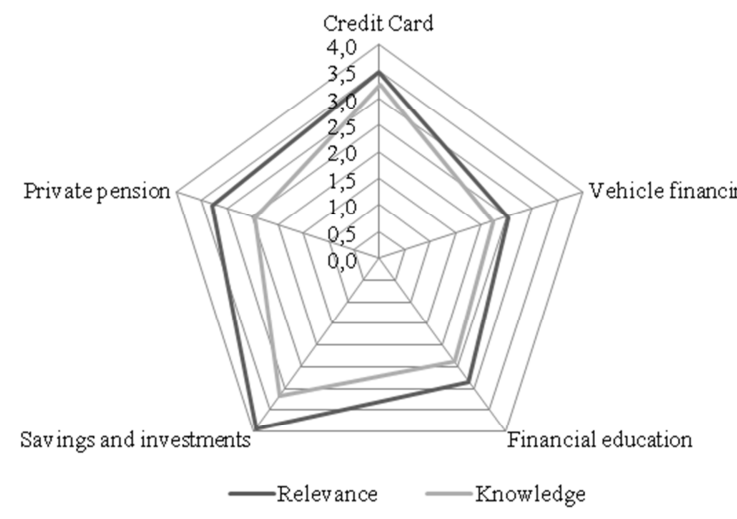

Male respondents $(\mathrm{N}=377[49 \%])$

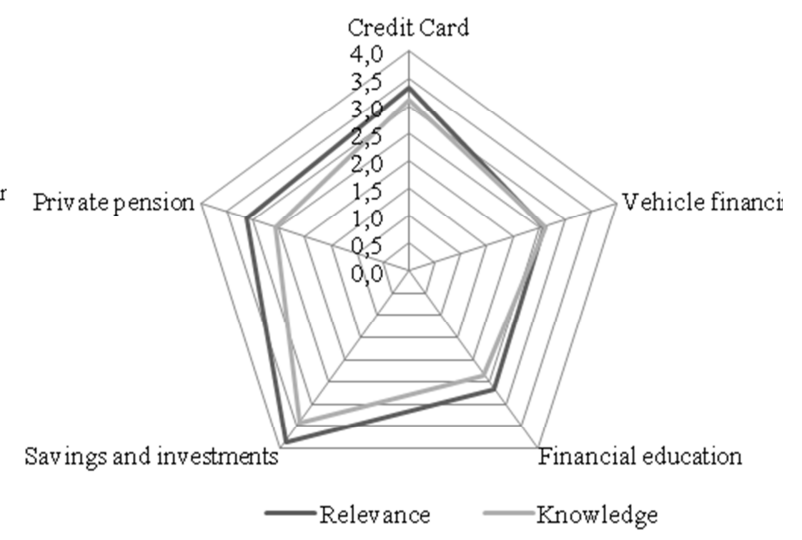

Figure 2. Perception of the Relevance and Knowledge of Financial Products (as Judged by the Respondent Students).

The graph on the left represents the average values for the relevance and knowledge (self-declared) of financial products on the part of female respondents and on the right are the responses from male students. The points scale considers 1 (no relevance/knowledge) to 5 (a lot of relevance/knowledge).

Slightly more respondents were female $(\sim 51 \%)$, as seen in Table 2 . They are also in the majority of the 552 students who have credit cards $(\sim 52.5 \%)$. However, male students are in the majority (54.6\%, compared with $45.0 \%$ found by Lyons (2004) in the North American market) among students in the group of individuals who use credit cards and display one or more of the risk behaviors considered in this research.

\section{Logit regression analysis}

The quality of the results obtained was analyzed, based on four measures: (a) $R^{2}$ of MacFadden (Aldrich \& Nelson, 1984); (b) percentage of events classified correctly; (c) Likelihood ratio; (d) Homoscedastic error term test, $u_{i}$, of the regression. The first two measures are used to illustrate the adjustment level of the estimated model and the third indicates whether the explanatory variables jointly do not have an effect on the dependent variable. The last measure is a diagnosis to check if the results obtained are valid.

Table 3 and Table 4 show the results obtained in the simulations. In the upper part are the estimated coefficients for the explanatory models of the dependent variables $(y=1)$ : (a) having a negative balance equal to or greater than $\mathrm{R} \$ 1000$; (b) having a credit card bill that was at least two months overdue; (c) not paying off the credit card bill in full; (d) having at least one of the risk behaviors observed. The results obtained in the simulation of the explanatory model of one of the five dependent variables studied were suppressed; i.e. when someone uses a full limit of a credit card, bearing in mind that their results were judged to be insignificant in light of the measures adopted for diagnosing the quality of the models. The first columns of Table 3 and Table 4 give the 22 independent variables. To the right of each is the respective estimated $\beta_{i}$ parameter, the standard error and the significance, which suggests the marginal effect on the conditional probability of the dependent variable.

With regard to the arguments defended by researchers like Joo, Grable and Bagwell (2001), who assume that maintaining significant debt balances constitutes risk behavior on the part of students in their dealings with credit cards, Table 3 displays substantial signs that students who have more than 3 credit cards $\left(\beta_{1} \cong 1.5156 ; \mathrm{p}<0.01\right)$ tend to be more likely to have 
balances over $\mathrm{R} \$ 1,000.00$. This result also supports Black's theory (2001), that individuals who have a large number of credit cards tend to adopt compulsive behaviors in their purchases, acquiring goods and services that are of little use (Roberts \& Jones, 2001).

According to Norvilitis and MacLean (2010), young adults may hold an incentive to use credit cards to increase their well being. We found that to be financially independent of parents seems to have a marginally positive effect $\left(\beta_{18} \cong 0.5985, \mathrm{p}<0.1\right)$ on the propensity to maintain high outstanding balances on credit cards. Therefore, students seem inclined to agree to pay interest on the maintenance of balance due, even if they do not know the high interest rates charged in Brazil $\left(\beta_{3} \cong-0.7748, p<0.01\right)$ in the name of a possible increase in well being. This fact is confirmed by the estimated coefficients for the way they use credit cards: (a) general expenses $\left(\beta_{12} \cong 0.9038, \mathrm{p}<0.01\right)$, (b) travel expenses and car $\left(\beta_{9} \cong 0.5985, \mathrm{p}<0,1 ; \beta_{8} \cong\right.$ $0.8376, \mathrm{p}<0.01)$.

Therefore, these individuals act in such a way as to seek to reduce their high levels of anxiety, or even to try and acquire social status, acceptance and recognition in their social group by means of consumption that is not very rational (John, 1999). In addition, students who are in a relationship seem to have a greater propensity for assuming large debt balances $\left(\beta_{16} \cong 1.0770\right.$; $\mathrm{p}<0.1)$. The estimated model for the probability of maintaining a debit balance equal to or greater than $R \$ 1,000.00$ (see Table 3) received a correct classification percentage of events close to $83.5 \%$, and the likelihood ratio test $\left(\chi^{2}=96.4727 ; \mathrm{p}<0.01\right)$ suggests that the explanatory variables together seem to exercise a significant marginal effect on the dependent variable. As found in the simulations of the model whose dependent variable was the maintenance of balance due on your credit card, when considering the habit of delaying payment of the invoice from the card (the fourth column of Table 3), individuals possessing three or more cards were more likely to behave less responsibly $\left(\beta_{2} \cong 0.7456, p<0.1\right)$. In this same model, the males are less likely to adopt behavior $\left(\beta_{15} \cong-0.5960, \mathrm{p}<0.1\right)$, ceteris paribus.

Table 3

Probability (Logit) of Students Adopting Financial Risks with Debt and the Punctual Payment of Bills (Students with Credit Cards)

\begin{tabular}{lcccccc}
\hline & \multicolumn{3}{c}{$\begin{array}{c}\text { Having a credit card debt } \\
\text { Variable }\end{array}$} & $\begin{array}{c}\text { Being unpunctual (more } \\
\text { than 2 months overdue) }\end{array}$ \\
\cline { 2 - 7 } & $\begin{array}{c}\text { Marginal } \\
\text { effect }\end{array}$ & $\begin{array}{c}\text { Standard } \\
\text { error }\end{array}$ & $\begin{array}{c}\text { Marginal } \\
\text { effect }\end{array}$ & $\begin{array}{c}\text { Standard } \\
\text { error }\end{array}$ \\
\hline Constant & -3.0360 & 0.7531 & $* * *$ & -2.0054 & 0.9308 & $* *$ \\
1. Has more than 3cc & 1.5156 & 0.3005 & $* * *$ & 0.7456 & 0.3843 & $*$ \\
2. Obtained cc during/after university & -0.2668 & 0.2924 & & 0.0886 & 0.3836 \\
3. Knows cc interest rates & -0.7748 & 0.2846 & $* * *$ & -0.4886 & 0.3704 \\
4. Uses cc to pay education expenses & 0.0335 & 0.3387 & & -0.5533 & 0.5757 \\
5. Uses cc to buy clothes and personal items & -0.0241 & 0.3076 & -0.5045 & 0.3997 \\
6. Uses cc to buy meals & -0.1570 & 0.3470 & -0.2931 & 0.4100 \\
7. Uses cc for entertainment expenses & -0.0595 & 0.3207 & & 0.1710 & 0.3900 \\
8. Uses cc for automobile expenses & 0.8376 & 0.2934 & $* * *$ & -0.5176 & 0.4943 \\
9. Uses cc for travel expenses & 0.5517 & 0.3009 & $*$ & -0.8551 & 0.5728 \\
\hline
\end{tabular}


Table 3 (continued)

\begin{tabular}{|c|c|c|c|c|c|c|}
\hline \multirow[b]{2}{*}{ Variable } & \multicolumn{3}{|c|}{$\begin{array}{l}\text { Having a credit card debt } \\
\quad \geq \mathrm{R} \$ 1,000\end{array}$} & \multicolumn{3}{|c|}{$\begin{array}{l}\text { Being unpunctual (more } \\
\text { than } 2 \text { months overdue) }\end{array}$} \\
\hline & $\begin{array}{c}\text { Marginal } \\
\text { effect }\end{array}$ & $\begin{array}{l}\text { Standard } \\
\text { error }\end{array}$ & & $\begin{array}{c}\text { Marginal } \\
\text { effect }\end{array}$ & $\begin{array}{l}\text { Standard } \\
\text { error }\end{array}$ & \\
\hline 10. Uses cc for rent expenses & -1.0644 & 1.0311 & & 1.9090 & 0.8391 & $* *$ \\
\hline 11. Uses cc to pay bills in general & 0.5445 & 0.5041 & & 0.8956 & 0.5922 & \\
\hline 12. Uses cc for other expenses & 0.9038 & 0.3371 & $* * *$ & 0.4886 & 0.5137 & \\
\hline $\begin{array}{l}\text { 13. Would take a personal finance course at } \\
\text { university }\end{array}$ & -0.2869 & 0.4037 & & 0.3633 & 0.4928 & \\
\hline 14. Would do an online personal finance course & 0.5715 & 0.3698 & & 0.5950 & 0.4402 & \\
\hline 15. Male & 0.3679 & 0.2799 & & -0.5960 & 0.3563 & $*$ \\
\hline 16. In a relationship & 1.0770 & 0.6318 & $*$ & 0.3636 & 0.8224 & \\
\hline 17. 1st generation in family to university & -0.3965 & 0.4737 & & 0.3733 & 0.4367 & \\
\hline 18. Financially independent of parents & 0.5985 & 0.3059 & * & 0.4456 & 0.3727 & \\
\hline 19. Lives in residence hall or rented property & 0.0092 & 0.4413 & & -0.4928 & 0.5863 & \\
\hline 20. Family lives in own house & 0.5001 & 0.5057 & & -0.7554 & 0.5168 & \\
\hline 21. Financial situation affects study concentration & 0.3990 & 0.3699 & & 0.4083 & 0.4065 & \\
\hline $\begin{array}{l}\text { 22. Has had trouble sleeping because of finance } \\
\text { situation }\end{array}$ & 0.4161 & 0.3389 & & 0.0214 & 0.4002 & \\
\hline $\mathrm{N}$ with $y=1$ (Total num. considered in simulation) & 95 & (496) & & 41 & (496) & \\
\hline $\mathrm{R}^{2 \text { of }} \mathrm{McFadden}$ & 0.1991 & & & 0.1310 & & \\
\hline$\%$ of correct classifications & $83.5 \%$ & & & $92.1 \%$ & & \\
\hline Akaike's information criterion & 434.0570 & & & 291.8502 & & \\
\hline$\chi^{2}$ likelihood ratio test & 96.4727 & $* * *$ & & 37.0896 & $* *$ & \\
\hline
\end{tabular}

Note. This Table shows the results obtained for the estimated coefficients for the Logit model for the two dependent variables (of the four used in this research). The initial set of data comprised 769 respondents, of whom 552 had a credit card, was smaller after discarding incomplete observations the number $\mathrm{N}$ of observations used in the regressions (reported in the lower part of the Table). The standard error for each marginal effect is indicated in the column to the right of each coefficient. Source: The estimates were obtained with a robust standard error, using the procedure suggested by Davidson, R., \& Mackinnon, J. G. (2004). Econometric theory and methods (p. 250). New York: Oxford University Press. cc $=$ credit card. Estimates obtained using the Eviews 7.0® (2009). (Version 7) [Software]. New York, NY, USA: Quantitative Micro Software.

The p-values are represented by: $* \mathrm{p}<0.10 ; * \mathrm{p}<0.05 ; * * * \mathrm{p}<0.01$.

Table 4 presents the results for two dependent variables that define the behavior seen as risky: (a) partial payment of the credit card bill, (b) takes at least one of the four risk behaviors. Here we emphasize that one of the behaviors seen as risky didn't achieve significant results, so we chose not to report its estimates. Among the results obtained for partial payment, we note that individuals who are in a stable relationship were less likely to make partial payments $\left(\beta_{16} \cong\right.$ -2.0612, $\mathrm{p}<0.01$ ). Concerning the maintenance of debit balances, the fact of knowing the interest rates exerted a negative marginal effect on the probability of realizing partial payments of credit card bills $\left(\beta_{3} \cong-0.7923, \mathrm{p}<0.05\right)$. This result is in line with the idea that higher levels of financial literacy can lead young adults to behave in more responsible and balanced use of credit cards. 
Table 4 shows that when an individual alleges he/she knows the interest rates charged by the administrators of credit cards, there seems to be a significant association $\left(\beta_{3} \cong-0.6555 ; \mathrm{p}<\right.$ 0.01 ) with at least one of the four risk behaviors considered in this research. In other words, the marginal effect caused by the fact of knowing the interest rates reduces the probability of assuming risk behavior.

Table 4

Probability (Logit) Being Financially Risky with Regard to Full Payment and Presenting some Risk Behavior (Students with Credit Cards)

\begin{tabular}{|c|c|c|c|c|c|c|}
\hline \multirow[b]{2}{*}{ Variable } & \multicolumn{3}{|c|}{$\begin{array}{l}\text { Paying only partial amounts of } \\
\text { the bill }\end{array}$} & \multicolumn{3}{|c|}{ Having risk behavior } \\
\hline & $\begin{array}{c}\text { Marginal } \\
\text { effect }\end{array}$ & $\begin{array}{l}\text { Standard } \\
\text { error }\end{array}$ & & $\begin{array}{l}\text { Marginal } \\
\text { effect }\end{array}$ & $\begin{array}{l}\text { Standard } \\
\text { error }\end{array}$ & \\
\hline Constant & $-0,3732$ & 0,7171 & & $-0,5008$ & 0,5428 & \\
\hline 1. Has more than $3 \mathrm{cc}$ & 0,5047 & 0,3405 & & 1,2102 & 0,2914 & $* * *$ \\
\hline 2. Obtained cc during/after university & $-0,4944$ & 0,3060 & & $-0,2201$ & 0,2246 & \\
\hline 3. Knows cc interest rates & $-0,7923$ & 0,3101 & $* *$ & $-0,6555$ & 0,2167 & $* * *$ \\
\hline 4. Uses cc to pay education expenses & 0,0496 & 0,3710 & & $-0,1662$ & 0,2715 & \\
\hline $\begin{array}{l}\text { 5. Uses cc to buy clothes and } \\
\text { personal items }\end{array}$ & $-0,6459$ & 0,2993 & $* *$ & $-0,3295$ & 0,2340 & \\
\hline 6. Uses cc to buy meals & $-0,3268$ & 0,3573 & & $-0,2889$ & 0,2516 & \\
\hline $\begin{array}{l}\text { 7. Uses cc for entertainment } \\
\text { expenses }\end{array}$ & $-0,2197$ & 0,3340 & & 0,0224 & 0,2393 & \\
\hline 8. Uses cc for automobile expenses & $-0,1993$ & 0,3641 & & 0,4834 & 0,2507 & $*$ \\
\hline 9. Uses cc for travel expenses & $-0,4895$ & 0,3857 & & $-0,1701$ & 0,2414 & \\
\hline 10. Uses cc for rent expenses & $-0,1293$ & 0,9516 & & $-0,7683$ & 0,7537 & \\
\hline 11. Uses cc to pay bills in general & 0,7997 & 0,5703 & & 0,5068 & 0,4066 & \\
\hline 12. Uses cc for other expenses & 0,6159 & 0,4179 & & 0,6155 & 0,3296 & $*$ \\
\hline $\begin{array}{l}\text { 13. Would take a personal finance } \\
\text { course at university }\end{array}$ & $-0,5036$ & 0,3537 & & $-0,4505$ & 0,3013 & \\
\hline $\begin{array}{l}\text { 14. Would do an online personal } \\
\text { finance course }\end{array}$ & 0,2541 & 0,3463 & & 0,3591 & 0,2703 & \\
\hline 15. Male & $-0,2309$ & 0,3091 & & 0,4686 & 0,2215 & $* *$ \\
\hline 16. In a relationship & $-2,0612$ & 0,7731 & $* * *$ & 0,3282 & 0,5349 & \\
\hline $\begin{array}{l}\text { 17. 1st generation in family to } \\
\text { university }\end{array}$ & 0,2567 & 0,4289 & & $-0,0830$ & 0,3620 & \\
\hline 18. Financially independent of parents & 0,4515 & 0,3048 & & 0,4486 & 0,2421 & * \\
\hline $\begin{array}{l}\text { 19. Lives in residence hall or rented } \\
\text { property }\end{array}$ & $-0,2591$ & 0,4349 & & 0,0844 & 0,3115 & \\
\hline 20. Family lives in own house & $-0,3700$ & 0,4520 & & $-0,2310$ & 0,3672 & \\
\hline
\end{tabular}


Table 4 (continued)

\begin{tabular}{|c|c|c|c|c|c|c|}
\hline \multirow[b]{2}{*}{ Variable } & \multicolumn{3}{|c|}{$\begin{array}{l}\text { Paying only partial amounts of } \\
\text { the bill }\end{array}$} & \multicolumn{3}{|c|}{ Having risk behavior } \\
\hline & $\begin{array}{l}\text { Marginal } \\
\text { effect }\end{array}$ & $\begin{array}{l}\text { Standard } \\
\text { error }\end{array}$ & & $\begin{array}{l}\text { Marginal } \\
\text { effect }\end{array}$ & $\begin{array}{l}\text { Standard } \\
\text { error }\end{array}$ & \\
\hline $\begin{array}{l}\text { 21. Financial situation affects study } \\
\text { concentration }\end{array}$ & 0,8222 & 0,4034 & $* *$ & 0,6698 & 0,3480 & * \\
\hline $\begin{array}{l}\text { 22. Has had trouble sleeping because } \\
\text { of finance Situation }\end{array}$ & 0,4287 & 0,3793 & & 0,2265 & 0,3020 & \\
\hline $\begin{array}{l}\mathrm{N} \text { with } y=1 \text { (Total } \mathrm{N} \text { considered in } \\
\text { simulation) }\end{array}$ & 70 & (496) & & 172 & (496) & \\
\hline $\mathrm{R}^{2}$ of McFadden & 0,1254 & & & 0,1222 & & \\
\hline$\%$ of correct classification & $86,7 \%$ & & & $71,6 \%$ & & \\
\hline Akaike's criterion & 399,1068 & & & 608,0205 & & \\
\hline$\chi^{2}$ Likelihood ratio test & 50,6449 & $* * *$ & & 78,2429 & $* * *$ & \\
\hline
\end{tabular}

Note. This Table shows the results obtained for the estimated coefficients for the Logit model for two dependent variables (not paying off the whole of the bill and having at least one risk behavior in the use of a credit card). The initial set of data comprised 769 respondents, of whom 552 had credit cards, was smaller after discarding incomplete observations the number $\mathrm{N}$ of observations used in the regressions (reported in the lower part of the Table). The standard error for each marginal effect is indicated in the column to the right of each coefficient. Estimates were obtained with a robust standard error, using the procedure suggested by Davidson, R., \& Mackinnon, J. G. (2004). Econometric theory and methods (p. 250). New York: Oxford University Press. According to the verisimilitude ratio test $\left(\chi^{2}=19.0521\right)$, the model estimated for use of the full limit of the credit card seemed not to be very significant. cc $=$ credit card. Estimates were obtained using Eviews 7.0® (2009). (Version 7) [Software]. New York, NY, USA: Quantitative Micro Software. The parameters estimated for the fourth risk behavior, the fact that the student fully uses his/her credit card limit, were suppressed because they did not give satisfactory results for the adjustment measures used in this research.

The p-values are represented by: *p $<0.10 ; * * \mathrm{p}<0.05 ; * * * \mathrm{p}<0.01$.

This suggests that a better level of education in personal finance may constitute a means of reducing the number of students at risk from using credit cards. Put another way, making students more aware of the cost of capital belonging to the institutions that administer credit cards may reduce their likelihood of using this type of funding; this line of argument supports the arguments of authors like Agarwal and Liu (2003). Furthermore, Brazil is considered to be a market whose basic interest rate is one of the highest in the world (see Figure 3). 


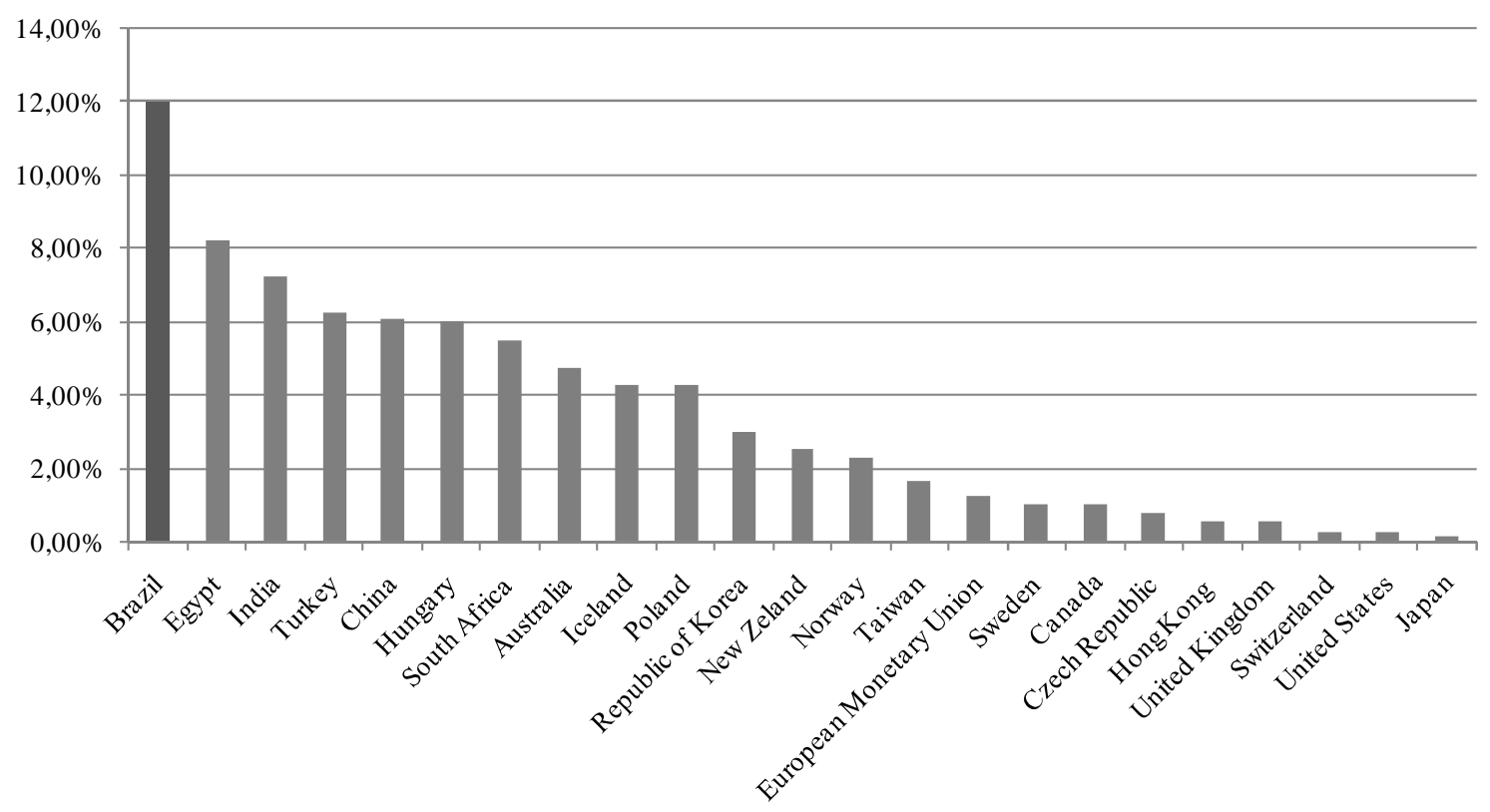

Figure 3. Current Annual Central Bank Interest Rates around the World in May 2011.

Source: Prepared by the authors based on Bloomberg L.P. (2011). Current annual central bank interest rates. [Computer System]. Bloomberg terminal. New York, USA: Author.

Also with regard to what is reported in Table 4, in line with what Black (2001) suggests, it seems that having a larger number of credit cards is associated with a greater likelihood of a student adopting some risk behavior $\left(\beta_{1} \cong 1.2102 ; \mathrm{p}<0.01\right)$. Of the four models reported in this section, in only one of them was the number of cards not significantly associated with risk behavior. The greatest marginal effect on the dependent variable was found in the explanatory model of the behavior of having a debit balance on the credit card equal to or greater than $\mathrm{R} \$$ $1,000.00\left(\beta_{1} \cong 1.5156 ; \mathrm{p}<0.01\right)$, as detailed in Table 3. According to Woodruffe (1997), students with this type of behavior look for well-being vis-à-vis a reduction in high levels of anxiety. In short, according to the student's behavioral orientation, the use of the credit card may constitute an attempt to hide difficulties and weaknesses related to their personality (Faber $\&$ Christenson, 1996). By way of illustration and interpretation of the coefficients estimated as significant, the probability of an individual having at least one risk behavior (see Table 4) would be approximately expressed as follows (5):

$$
\ln \left(\frac{\pi_{i}}{1-\pi_{i}}\right)=-0,5008+1,2102 \beta_{1}+\cdots+0,6698 \beta_{21}
$$

Therefore, the probability, $\pi_{i}$, that a student $\left(\beta_{15}=0\right)$, who is financially independent $\left(\beta_{18}\right.$ $=1$ ), aware that their financial situation can affect their academic performance $\left(\beta_{21}=1\right)$, who has more than 3 credit cards $\left(\beta_{1}=1\right)$, knows the interest rates charged by their operator $\left(\beta_{3}=1\right)$, is used to using their credit card to pay automobile expenses $\left(\beta_{8}=1\right)$ in addition to other bills $\left(\beta_{12}=1\right)$ would adopt at least one of the risk behaviors, would be calculated according to the following expression (6).

$$
\pi_{i}=\frac{1}{1+e^{-\pi}} \therefore \frac{1}{1+2,718^{-(1,21-0,65+0,48+0,61+0+0,44+0,66)}} \therefore \pi_{i} \cong 0,9411
$$

Along this same line of thinking, but with regard to the impact that the financial situation may have on academic performance and well-being, observing the results of the estimates summarized in Table 4, it can be noted that the probability of the student not paying off the whole of the bill $\left(\beta_{21}=0.8222 ; \mathrm{p}<0.05\right)$ and the probability of having at least one of the risk behaviors being looked at $\left(\beta_{21}=0.6698 ; \mathrm{p}<0.1\right)$ is significantly greater among those who perceive that their concentration has been compromised because of their credit card debts. 
These results support the ideas argued by Norvilitis and Santa Maria (2002), according to which individuals who adopt risk behavior tend to have a greater stress level, which in some cases is reason for them committing suicide. This thinking supports the premise that positive behaviors when using credit cards constitute a means of maximizing well-being, to the extent that this financial instrument can offer convenience (Bernthal, Crockett, \& Rose, 2005).

If the observed behavior of the subjects is compared according to sex and marital status, the evidence suggests that individuals involved in stable relationships tend to have higher debt balances $\left(\beta_{16} \cong 1.0770, \mathrm{p}<0.1\right)$, but try to pay off their invoices in full $\left(\beta_{16} \cong-2.0612, \mathrm{p}<\right.$ 0.01 ): the behavior of keeping outstanding balances was significant, but with $\mathrm{p}<0.1$, and at a lower marginal effect. In addition, male subjects were less likely to delay payments $\left(\beta_{15} \cong-\right.$ $0.5960, \mathrm{p}<0.1)$, but more likely to take at least one risk behavior $\left(\beta_{15} \cong 0.4686, \mathrm{p}<0.05\right)$.

\section{Final Considerations}

The primary objective of this research was to check for the existence of associations between the profile of university students in the main financial center of a prominent emerging market, São Paulo, Brazil, and behavior considered risky in the use of credit cards. To do so we used the regressions' procedure with a binary response variable (logit models). 769 valid questionnaires were collected, from which 552 respondents alleged they both had and used credit cards. There were two main empirical results.

First, the estimated parameters in the regressions suggest that the number of credit cards that students use may significantly influence the likelihood of them developing behaviors seen as risky, as Black (2001) argues. Secondly, there are significant indications that financial education can influence the behavior of students vis-a-vis their propensity for adopting risky behavior in their use of credit cards. In other words, students who alleged they knew the interest rates charged by the card administrators were, on average, less likely to adopt risky behaviors. Finally, there was significant resistance (62\% of participants did not respond or do not know) to answer questions related to the amount of family income. However, only $15 \%$ of respondents claimed that their parents pay their credit card bills, suggesting that students are fairly responsible for using credit cards. Or rather, assuming that the participants are college age, it is understood that controlling for the level of family income does not compromise the results of this article.

With regard to limitations of the research the following can be mentioned: (a) data collection was restricted to a particular moment in the economy and to a metropolitan region with explicit peculiarities; (b) a fairly homogenous respondent public, e.g. age and income level, which makes it difficult to generalize from empirical findings; (c) the trustworthiness of the responses collected from the respondent public. The following are some of the practical implications of this research: (a) positive financial behavior can be promoted through financial education on the university campus, which directly increases student well-being; (b) students need a better understanding of the importance of credit management and savings, thus avoiding risky behavior when using a credit card; (c) there is room for financial teachers and college administrators to encourage students to develop positive financial behavior, such as by developing integration programs between parents and their children; (d) financial education programs can pay special attention to how to approach financially at-risk students, possibly forming groups with specific topics that are relevant to them.

The issues previously highlighted, as well as the limitations that are inherent in the design adopted in this research, are linked with the lack of studies that consider the Brazilian situation and suggest a promising research field in finance. The following are some suggestions for future research: (a) test the models presented here, by expanding the group of respondents, especially 
in terms of the age bands and social strata (discussing the issue for groups that have profiles other than those of college students); (b) check for the existence of associations between individuals' profiles and the decision to use credit card services, since some individuals decide not to do so, even though there is reasonable consensus that this financial product makes a diversity of aspects possible that contribute to greater comfort and security in issues relating to consumption; (c) analyze the role of teaching institutions in delivering financial knowledge to university students; (d) explore the behavioral differences in the use of credit cards between different markets, as advocated by Allen and Jover (1997).

\section{Received 29 June 2011; received in revised form 25 May 2012.}

\section{Acknowledgements}

The authors are grateful to the Research Support Fund maintained by The School of Business Administration of Sao Paulo/Getulio Vargas Foundation (FGV/EAESP), which funded the research that fully supports this article. The authors also thank the two anonymous reviewers of The Brazilian Administration Review for their valuable comments. And finally, the suggestions received from participants EnAnpad 2011 (Rio de Janeiro/Brazil) and also the suggestions received from Professor Dominique Gehy (Florida State University), during The Eastern Finance Association Annual Meeting, held in April 2012, in Boston/MA were of merit.

\section{References}

Agarwal, S., \& Liu, C. (2003). Determinants of credit card delinquency and bankruptcy: macroeconomics factors. Journals of Economics and Finance, 27(1), 75-84. doi: 10.1007/BF02751591

Aldrich, J. H., \& Nelson, F. D. (1984). Linear probability, logit, and probit models. Beverly Hills, CA: Sage.

Allen, J. L., \& Jover, M. A. (1997). Credit card behavior of university students: ethnic differences. Consumer Interest Annual, 43, 162-170.

Bernthal, M. J., Crockett, D., \& Rose, R. L. (2005). Credit cards as lifestyle facilitators. Journal of Consumer Research, 32(1), 130-145.

Black, D. (2001). Compulsive buying disorder: definition, assessment, epidemiology and clinical management. CNS Drugs, 15(1), 17-27.

Bloomberg L. P. (2011). Current annual central bank interest rates [Computer System]. Bloomberg terminal. New York, USA: Author.

Brazilian Association of Credit Card and Service Companies. (2011). Indicadores de mercado. Retrieved from http://www.abecs.org.br/site2012/indicadores.asp

Cauchon, D. (2011, October 25). Student loans outstanding will exceed \$1 trillion this year. Usa Today. Retrieved from http://www.usatoday.com/money/perfi/college/story/2011-1019/student-loan-debt/50818676/1

Danes, S. M., \& Hira, T. K. (1987). Money management knowledge of college students. Journal of Student Financial Aid, 17(1), 4-16.

Davidson, R., \& Mackinnon, J. G. (2004). Econometric theory and methods. New York: Oxford University Press. 
Departamento de Pesquisas Econômicas do Bradesco. (2011, April). Destaque depec. Boletim Infomativo da Depec, (10).

Dietrich, J. K., \& Sorensen, E. (1984). An application of logit analysis to prediction of merger targets. Journal of Business Research, 12(3), 393-402. doi: 10.1016/01482963(84)90020-1

Eviews 7.0® (2009). (Version 7) [Software]. New York, NY, USA: Quantitative Micro Software.

Faber, R., \& Christenson, G. (1996). In the mood to buy: differences in the mood states experienced by compulsive buyers and other consumers. Psychology \& Marketing, 13(8), 803-819. doi: 10.1002/(SICI)1520-6793(199612)13:8<803::AID-MAR6>3.0.CO;2-J

Fan, J. X., \& Xiao, J. J. (1998). Consumer decision making styles of young-adult Chinese. Journal of Consumer Affairs, 32(2), 275-294. doi: 10.1111/j.1745-6606.1998.tb00410.x

Fogel, J., \& Schneider, M. (2011). Credit card use: disposable income and employment status. Young Consumers: Insight and Ideas for Responsible Marketers, 12(1), 5-14. doi: $10.1108 / 17473611111114740$

Hayhoe, C. R. (2002). Comparison of affective credit attitude scores and credit use of college student at two points in time. Journal of Family and Consumer Science, 94(1), 71-77.

Hayhoe, C. R., Leach, L. J., \& Turner, P. R. (1999). Discriminating the number of credit cards held by college students using credit and money attitudes. Journal of Economic Psychology, 20(6), 643-656. doi: 10.1016/S0167-4870(99)00028-8

Hayhoe, C. R., Leach, L. J., Turner, P. R., Bruin, M. J., \& Lawrence, F.C. (2000). Differences in spending habits and credit card use of college students. The Journal of Consumer Affairs, 34(1), 113-133. doi: 10.1111/j.1745-6606.2000.tb00087.x

John, D. R. (1999). Consumer socialization of children: a retrospective look at twenty-five years of research. Journal of Consumer Research, 26(3), 183-213. doi: 10.1086/209559

Joo, S. H., Grable, J. E., \& Bagwell, D. C. (2003). Credit card attitudes and behaviors of college students. College Student Journal, 37(3), 405-419.

Kahneman, D., Krueger, A. B., Schkade, D., Schwarz, N., \& Stone, A. A. (2006). Would you be happier if you were richer? A focusing illusion. Science, 312(5782), 1908-1910. doi: $10.1126 /$ science. 1129688

Kidwell, B., \& Turrisi, R. (2000). A cognitive analysis of credit card acquisition and college student financial development. The Journal of College Students Development, 41(6), 589599.

Lawrence, F. C., Cude, B. J., Lyons, A. C., Marks, L., \& Machtmes, K. (2006). College students' financial practices: a mixed methods analysis. The Journal of Consumer Education, 23, 13-26.

Luong, M. (2010). The financial impact of student loans. Perspectives on Labour And Income, 22(1), 29-42.

Lyons, A. C. (2004). A profile of financially at-risk college students. The Journal of Consumer Affairs, 38(1), 56-80. doi: 10.1111/j.1745-6606.2004.tb00465.x

Lyons, A. C. (2007). Credit practices and financial education needs of Midwest college students. Indianapolis, IN: Networks Financial Institute, Indiana State University. 
Lyons, A. C., Scherpf, E., \& Neelakantan, U. (2007). Intergenerational transfer of financial behaviors from parents to children (Working Paper), Networks Financial Institute, Indiana State University, Indianapolis, IN.

Lyons, A. C., \& Yilmazer, T. (2005). Health and financial strain and health: evidence from the survey of consumer finances. Southern Economic Journal, 71(4), 873-890.

MacFadyen, A. J., MacFadyen, H. W., \& Prince, N. J. (1996). Economic stress and psychological well-being: an economic psychological framework. Journal of Economic Psychology, 17(3), 291-311. doi: 10.1016/0167-4870(96)00012-8

Manning, R. D. (2000). Credit card nation: the consequences of America's addiction to credit. New York: Basic Books.

Mansfield, P. M., \& Pinto, M. B. (2007). Marketing credit cards to college students: will legislations protect them from excessive debt? Marketing Management Journal, 17(1), $112-22$.

Markovich, C. A., \& DeVaney, S. A. (1997). College seniors' personal finance knowledge and practices. Journal of Family \& Consumer Sciences, 89(3), 61-65.

Masuo, D. M., Malroutu, Y. L., Hanashiro, R., \& Kim, J. H. (2004). College students money beliefs and behaviors: an Asian perspective. Journal of Family and Economic Issues, 25(4), 469-481. doi: 10.1007/s10834-004-5491-z

Modigliani, F. (1998). The role of intergenerational transfers and life-cycle saving in the accumulation of wealth. Journal of Economic Perspectives, 2(2), 15-20.

Nellie Mae. (2005). Undergraduate students and credit cards in 2004: an analysis of usage rates and trends. Braintree, MA. Retrieved from http://inpathways.net/ccstudy_2005.pdf

Norvilitis, J. M., \& MacLean, M. G. (2010). The role of parents in college students' financial behaviors and attitudes. Journal of Economic Psychology, 31(1), 55-63. doi: 10.1016/j.joep.2009.10.003

Norvilitis, J. M., \& Santa Maria, P. (2002). Credit card debt on college campuses: causes, consequences and solutions. College Student Journal, 36(3), 357-364.

Pinto, M. B., Parente, D. H., \& Palmer, T. S. (2001). College student performance and credit card usage. The Journal of College Student Development, 42(1), 49-58.

Rindfleisch, A., Burroughs, J. E., \& Denton, F. (1997). Family structure, materialism, and compulsive consumption. Journal of Consumer Research, 23(4), 312-325. doi: $10.1086 / 209486$

Roberts, J. A., \& Jones, E. (2001). Money attitudes, credit card use, and compulsive buying among American college students. The Journal of Consumer Affairs, 35(2), 213-240. doi: 10.1111/j.1745-6606.2001.tb00111.x

Sánchez, M. (2010). Financial innovation and the global crisis. International Journal of Business and Management, 5(11), 26-31.

U.S. General Accounting Office. (2001). Consumer finance: college students and credit cards. (Report to Congressional Requesters \#GAO-01-773). Retrieved from http://www.gao.gov/new.items/d01773.pdf 
Veludo-de-Oliveira, T. M., Ikeda, A. A., \& Santos, R. C. (2004). Compra compulsiva e a influência do cartão de crédito. Revista de Administração de Empresas, 44(3), 89-94. doi: 10.1590/S0034-75902004000300007

Woodruffe, H. (1997). Compensatory consumption: why women go shopping when they're fed up and other stories. Marketing Inteligence\& Planning, 15(7), 325-334. doi: $10.1108 / 02634509710193172$

Xiao, J. J., Noring, F. E., \& Anderson, J. G. (1995). College students' attitudes towards credit cards. Journal of Consumer Studies and Home Economics, 19(2), 155-174. doi: 10.1111/j.1470-6431.1995.tb00540.x 


\section{APPENDIX}

\section{The Survey}

\section{SECTION \#1: Current Credit Usage and Knowledge:}

Q1. Do you have a credit card? Yes No

If your answer to question 1 is "No," skip to question 13. If your answer to question 1 is "Yes,"

continue to question 2.

Q2. How many credit cards do you have in your name? (Include bank cards, store cards, etc.) One

Two

Three

Four

Five or more

Q3. When did you obtain your first credit card?

Before beginning college

First year of college

After first year of college

Q4. What is the TOTAL amount you currently owe on ALL of your credit cards?

$\$ 0$ (I do not owe any money)

$\$ 1-\$ 499$

$\$ 500$ - \$999

$\$ 1,000-\$ 2,999$

$\$ 3,000$ - $\$ 4,999$

$\$ 5,000$ - $\$ 9,999$

$\$ 10,000$ or more

Not sure

Q5. In the last two years, have you ever been late on any of your credit card payments by 2 months or more?

Yes No

Q6. Thinking about last two years, how often do you pay off the ENTIRE BALANCE on your credit card(s)?

Almost always

Sometimes
Never

Q7. Thinking about last two years, how often do you "MAX OUT" your credit card(s)?

Almost always

Sometimes

Never

Q8. What is the "Annual Percentage Rate"

(APR) for the credit card you use the MOST?

Less than 5\% APR

$5 \%-9 \%$ APR

$10 \%-14 \%$ APR

$15 \%-20 \%$ APR

Higher than $20 \%$ APR

Not sure

Q9. What is the total "maximum amount" you can charge on the credit card you use the MOST?

$\$ 0$ - \$499

$\$ 500$ - \$999

$\$ 1,000-\$ 2,999$

$\$ 3,000$ - $\$ 4,999$

$\$ 5,000$ or more

Not sure

Q10. What do you usually purchase with your credit card(s)? (Check all that apply)

Textbooks/school supplies

Tuition and fees

Clothes and other personal items

Groceries

Eating out

Entertainment (movies, dance clubs, etc.)

Gas/auto maintenance/auto repair

Travel (airfare, hotel, rental car)

Rent/utilities

Other bills (cable, internet, cell phone)

Expenses related to

Fraternity/Sorority/Professional organizations

Other :

\section{SECTION \#2: Financial Education}

Q11. How important is each financial topic to you? Please rank on a scale from 1 to 5 with 1 being very

important and 5 being not important at all.

Personal financial management and budgeting

Credit cards and terms

Shopping for a car loan

Financing a college education

Saving and investing

Planning for retirement

Q12. How well is your understanding of each financial topic? Please rank on a scale from 1 to 5 with 1

being complete understanding and 5 being no understanding at all.

Personal financial management and budgeting

Credit cards and terms

Shopping for a car loan

Financing a college education

Saving and investing

Planning for retirement 
Q13. Would you register for an in-person course related to personal finance if offered on campus?

(Check only one)

Yes, only if the class was free

Yes, only if the class was offered for course credit

Yes, regardless of whether the class was

free or offered for credit No

Q14. Would you register if the course was offered online? (Check only one)
Yes, only if the class was free

Yes, only if the class was offered for

course credit

Yes, regardless of whether the class was

free or offered for credit No

Q15. Have you taken or are you currently taking any courses in high school or college related to personal finance?

Yes

No

\section{SECTION 3: Some Information About You:}

Q16. What is your age?

18-19

20-21

22-23

24-25

26-29

30-39

40-49

50 or older

Q17. What is your gender?

Male

Female

Q18. What is your primary ethnic background?

African American/Black

Asian

Hispanic

Native American

White

Other

Q19. What is your marital status?

Single with no children

Single with children

Married with no children

Married with children

Living as a couple

Q20. Are you the first person in your immediate family to go to college? Yes No
Q21. Are you financially independent from your parents (i.e. parents do not claim you on their tax return)?

Yes

No

Q22. What type of housing do you currently live in?

Residence Hall

Fraternity/Sorority

Apartment (rent)

House (rent)

Live at home with parents/relatives

Other

Q23. Do your parent(s) own or rent the residence they live in?

Own

Rent

Other

Q24. Does your financial situation affect your ability to concentrate on your studies? Yes No

Q25. Do you find yourself losing sleep or experiencing physical discomfort because of your financial situation? Yes No. 